\title{
Toxicity effects of sumithion on the breeding performance and viability of eggs, embryos and subsequent growth indices of Heteropneustes fossilis larvae
}

\author{
T. Das, M. M. Rahman ${ }^{*}$, M. S. Hossen and M. F. A. Mollah \\ Department of Fisheries Biology and Genetics, Bangladesh Agricultural University, Mymensingh-2202, Bangladesh \\ *E-mail: rahman.matiur@bau.edu.bd
}

\begin{abstract}
Sumithion, an organophosphate pesticide, has been used extensively in agriculture as well as in broodfish and nursery ponds in Bangladesh. Although it is being applied for beneficial purposes but eventually it exhibits some short and long term toxic effects to the aquatic ecosystem. Therefore, the present study investigated the toxic effects of sumithion on the breeding performance and subsequent viability of embryos and larvae of Heteropneustes fossilis. A total of 400 adult $H$. fossilis were equally stocked in two ponds. Sumithion at the dose of 0.24 ppm was applied for four months every 7 days interval in one pond while the rest one was considered as control. No significant $(p>0.05)$ difference was found in growth between the treated and control $H$. fossilis; however, fertilization and hatching rates of the eggs obtained from the treated group were significantly $(p>0.05)$ lower than that of control. Subsequently, the embryos and larvae produced from the broods of the control pond were exposed to 5 different concentrations of sumithion $(0.5,1.0,2.0,4.0$, and $8.0 \mathrm{ppm})$ against a control $(0 \mathrm{ppm})$. Each concentration was assessed in five replicates having 200 eggs. Data obtained from the sumithion acute toxicity tests were evaluated using the Probit Analysis. The mortality of embryos increased with the increasing sumithion concentrations from 0 to $8.0 \mathrm{ppm}$ and the significant $(p>0.05)$ differences were found only among the treated concentrations above $2.0 \mathrm{ppm}$. The $24 \mathrm{~h} \mathrm{LC}_{50}$ value for embryos was estimated to be $7.803 \mathrm{ppm}$. Dose-response decreased in hatching success and recorded as $90.8,85.0,76.2,73.0,65.0$, and $51.2 \%$ for control and 5 different concentrations of sumithion, respectively $(p<0.05)$. The numbers of dead larvae also increased significantly with the increasing sumithion concentrations exposed for 24$96 \mathrm{~h}$. The 24, 48, 72, and $96 \mathrm{~h} \mathrm{LC}_{50}$ values were estimated to be 8.677, 8.245, 7.664, and 6.782 ppm, respectively and these values were significantly $(p<0.05)$ different to each other. Besides, the larvae obtained from $0.5,2.0$, and $8.0 \mathrm{ppm}$ sumithion were reared against a control for 21 days to assess the residual effect. Significant negative effects on both growth and survival of the larvae were found among the sumithion concentrations used. The study therefore, suggested that sumithion has adverse and residual effects on the breeding performance along with early embryonic and larval development of $H$. fossilis even in lower concentration.
\end{abstract}

Keywords: Toxicity, Sumithion 50 EC, Heteropneustes fossilis, LC $_{50}$, Fertilized eggs, Larvae, Growth indices, Viability

\section{Introduction}

Pesticides are substances used to control pests, including insects, aquatic weeds, plant diseases, aquatic snails etc. These pesticides have been found to be highly toxic not only to fish but also to the other organisms, which constitute the food chain (Sabra and Mehana, 2015). Use of pesticides have been increased very extensively in agriculture, forestry, public health and in veterinary practices during the past two decades coinciding with changes in intensive farming practices. Although the pesticides are often very effective, many of them represent a potential hazard and some of them persist for a very long time in the environment and in most cases their impacts on the local fauna are unknown. Therefore, the uses of these pesticides worldwide give rise to concern on health and environmental effects.

Sumithion $50 \mathrm{EC}$, the O,O-Dimethyl O-(3-methyl-4-nitrophenyl) is one of the most frequently used pesticides in the agricultural region all over the world. Its principal use is to control a wide spectrum of chewing and sucking insects on rice, orchard fruits, vegetables, cereals, cotton, and forest (Minister et al., 1984). While such pesticides are used significantly for enhancing agricultural yield a certain portion are eventually transmitted and accumulated into the water body ensuing short and long term effects on the aquatic lives. Sumithion that reach into the aquatic habitats have been found to impair various physiological processes of fish (Bhuiyan et al., 2001). Accumulation of this toxic chemical is known to adversely affect many organs and systems of fish body such as the liver, kidney, thyroid gland, nervous 
system, immune system as well as reproductive system of fishes. Sumithion exposure decreases the hemoglobin content of tilapia and $30 \mathrm{ppm}$ sumithion has been found sufficient to kill all test fish within an hour (Koundinya and Ramamurthy, 1978; Haque and Barua, 1988). Ovarian recrudescence was also observed in Channa punctatus when treated with LC $_{50}$ dose of sumithion (Saxena and Sehgal, 1986). Even human body can be exposed to such hazardous chemicals down the food chain for instance through eating contaminated fish.

Stinging catfish, Heteropneustes fossilis is one of the important catfishes of Bangladesh with good market demand due to its palatability and less spine (Tripathi et al., 1997). It breeds in shallow inland waters during the onset of monsoon and is capable of breeding in ponds when sufficient rainwater accumulates (Talwar and Jhingran, 1992). Their eggs, embryos and larvae are often exposed to the toxicity of pesticides in nature when pesticides run off into natural water body from agricultural field. Moreover, in all $H$. fossilis nursery pond, sumithion is usually applied to control the Backswimmer, Notonecta glauca where it can render its toxicity to the water. Although a large number of experiments have been carried out to investigate the effects of sumithion on the various morphological and physiological aspects of fishes (Kabir et al., 2013; Sancho et al., 1998) and other aquatic organisms (Pawar and Katdare, 1982) little attempts have been undertaken to examine its effect on the developing fish embryo and larvae; the most sensitive stage in the life cycle of a teleost fish. Therefore, the present study was carried out to determine the toxicity effects of sumithion to $H$. fossilis on their breeding performance as well as incubation period, survivability, hatching rate of fertilized eggs and subsequent larval growth. The stinging catfish was selected for the bioassay experiment because of its wide distribution and currently cultured everywhere in Bangladesh.

\section{Materials and Methods}

\section{Brood fish and sumithion}

The study was carried out at the Mini Hatchery cum Breeding Complex, adjacent to the Faculty of Fisheries, Bangladesh Agricultural University (BAU), Mymensingh during the period on $1^{\text {st }}$ February to $30^{\text {th }}$ May 2015. A total of 400 adult $H$. fossilis (average length: $20.77 \mathrm{~cm}$, average weight: $30.25 \mathrm{~g}$ ) were collected from the haor of Mohanganj, Netrakona, Bangladesh without any injury and transported to the study area through oxygenated polythene bags. Upon arrival at the hatchery the fish were acclimatized in the cistern $\left(1.23 \times 2.44 \times 0.46 \mathrm{~m}^{3}\right)$ for one week and then stocked in two brood rearing ponds of 2 decimal sizes each for a period of 4 months to monitor growth and breeding performances. Length and weight of 8 fish from each pond were recorded monthly. One of the two ponds was considered as experimental pond and the other as control. In experimental pond sumithion at the dose of $0.24 \mathrm{ppm}$ was applied every 7 days interval while the control pond did not receive any pesticide dose. Before stocking the fish, ponds were prepared properly to produce sufficient natural food. Fish were fed with Quality premium; crumble-2 feed at $5 \%$ of their body weight. Both the ponds were under same management practices. Sumithion 50 EC (50\% Fenitrothion), the product of Sumitomo Chemical Company Limited (Japan), was purchased from the Setu Agro Industries Limited, Bangladesh

\section{Induced breeding and collection of fertilized eggs}

Ten pairs of healthy and sexually mature $H$. fossilis were selected from both of the sumithion treated and control ponds on the basis of some external features. The gravid females were identified by the presence of soft and swollen abdomen as well as round and bulged urogenital papillae. The males were recognized by their flat abdomens and long protruding genital papillae (Fig. 1). In addition, the maturity of the ripe female was confirmed by a slight pressure on the ventral side of the fish for oozing of eggs. The selected broods were kept in cistern for about $6 \mathrm{~h}$ for conditioning to the new environment and constant water supply was maintained to ensure proper aeration. The female and male fish were artificially induced by intra-muscular injection with $50 \mathrm{mg}$ carpPG/kg bw and $25 \mathrm{mg}$ carpPG/kg bw, respectively. The induced breeding technique was same for both the sumithion treated and control group. Hormone injected fishes were then kept in separate hapas set within the cistern providing continuous water flow through porous PVC pipe (Fig. 2). After $12 \mathrm{~h}$ of hormone administration, females released eggs naturally and males also released their sperm to fertilize the eggs. Similar tendency was seen in both sumithion treated and control groups. The fertilized eggs were collected separately from the hapas. The fertilized eggs from the control 
group were immediately placed in experimental units for embryo toxicity assay. Simultaneously, fertilization rate, incubation period and hatching rate of sumithion exposed fish were recorded. A portion of fertilized eggs were released into the glass aquarium to obtain hatchlings for the larval bioassay studies.
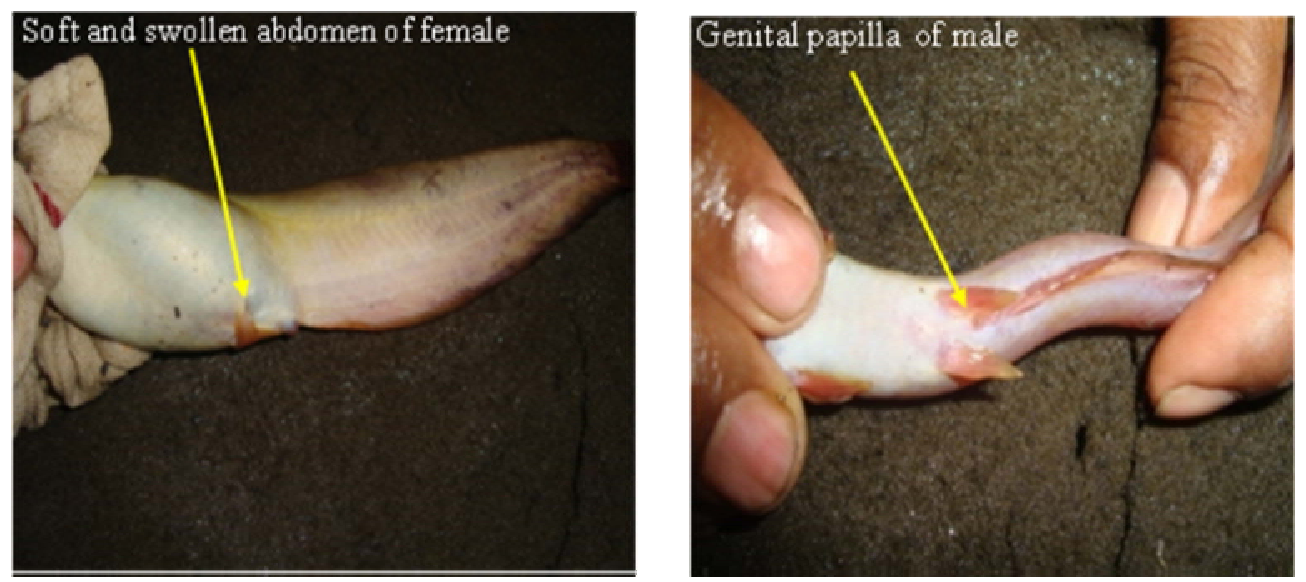

Fig 1. Brood female and male of Heteropneustes fossilis showing (a) soft and swollen abdomen of female and (b) long protruding genital papilla of male
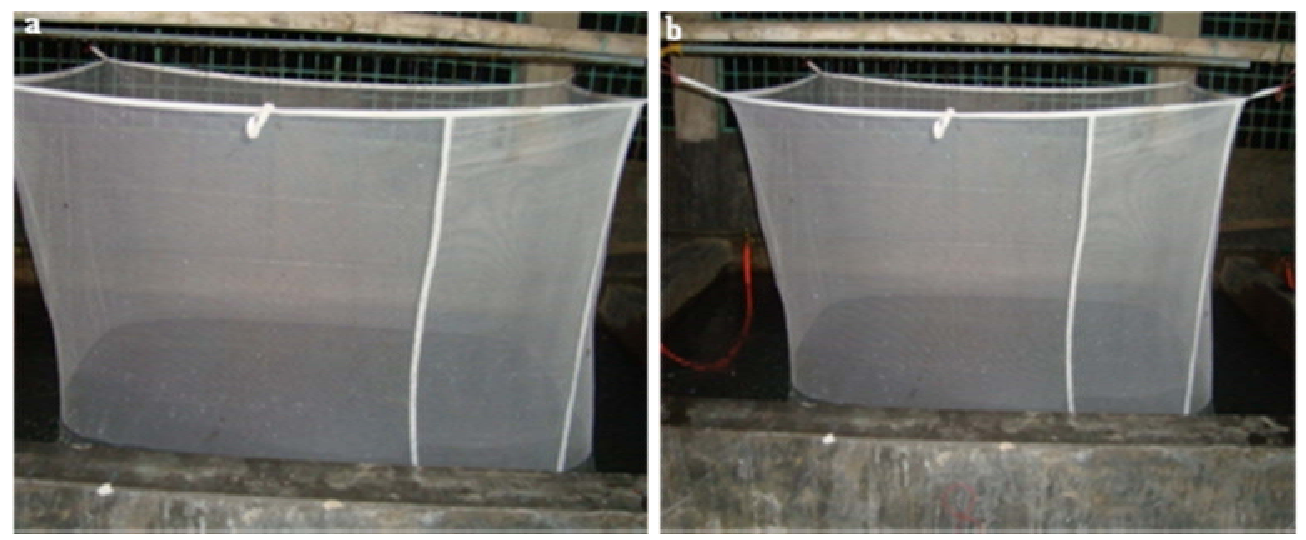

Fig 2. Hapa set in two adjacent cisterns for breeding of Heteropneustes fossilis (a) sumithion treated and (b) untreated

\section{Effects of sumithion on the viability of embryo}

Stock solution (1000 ppm) was prepared by dissolving a weighed amount of sumithion in distilled water. Then the appropriate amount of stock solution was taken into a glass jar and required amount of tap water was added in order to prepare the desired concentrations of $0.5,1.0,2.0,4.0$, and $8.0 \mathrm{ppm}$ for embryonic and larval bioassay. The jar was then gently stirred to ensure complete mixing. The control $(0$ ppm) group was exposed to tap water. Approximately 6000 fertilized eggs of $H$. fossilis were randomly selected and exposed to previously prepared sumithion concentrations in plastic bowls as treatments with a control for assessing the effects of sumithion on the fertilized eggs. Each bowl was $6 \mathrm{~cm}$ deep having an internal diameter of $16 \mathrm{~cm}$ with effective water holding capacity of $1 \mathrm{~L}$ (Fig. 3). All the treatments were replicated five times. Therefore, a total of 30 plastic bowls were used having 200 eggs in each and the experiment was allotted following randomized complete block design (RCBD). Continuous oxygenation was ensured with the help of aerator connected with plastic tubes. Water quality characteristics of the experimental units were determined according to APHA $(1985)^{[12]}$. The mean values for test water qualities were as follows: temperature $25.0 \pm 1.0^{\circ} \mathrm{C}, \mathrm{pH} 7.3 \pm 0.3$, dissolved oxygen $7 \pm 0.2 \mathrm{mg} / \mathrm{L}$ and total 
hardness $34.0 \pm 4.7 \mathrm{mg} / \mathrm{L}$. Every after $6 \mathrm{~h}$ of incubation, the numbers of dead and mouldy eggs afterward dead larvae were counted and removed. Upon completion of hatching, the survival rate, hatching rate and incubation periods were determined using the following formulae:

Survival rate $(\%)=\frac{\text { Number of eggs alive }}{\text { Totalnumber of eggs stocked }} \times 100$
Hatching rate $(\%)=\frac{\text { Number of eggshatched }}{\text { Totalnumber of eggs }} \times 100$
Incubation period $(h)=$ Hatching time - Fertilization time

To study the larval toxicity, around 200 hatchlings were set into each aquarium and every test concentrations and control groups were executed with five replicates from the stock aquarium. After 24 , 48, 72, and $96 \mathrm{~h}$ exposure periods to six different concentrations of sumithion, dead larvae in experimental and control groups were counted.

\section{Growth indices of larvae produced from sumithion treated eggs}

The larvae produced from three different sumithion concentrations $(0.5,2.0$, and $8.0 \mathrm{ppm})$ were reared for 21 days to inspect subsequent toxicity effects of sumithion on growth indices. Around 1600 larvae of 5 days old having initial weight of $7.6 \pm 1.52 \mathrm{mg}$ and length of $5.0 \pm 0.71 \mathrm{~mm}$ were collected and kept into separate plastic bowls. Each group was again replicated four times along with control bearing 100 eggs in each. The experimental bowl was $21 \mathrm{~cm}$ deep having an internal diameter of $32 \mathrm{~cm}$ with an effective water holding capacity of $10 \mathrm{~L}$ and facilitated for continuous flow of water from the porous PVC pipes as inlet along with outlet facilities (Fig. 4). The larvae were fed with live chopped Tubificid worms up to satiation level twice daily, once in the morning (8:00 am BDT) and next in the afternoon (5:00 pm BDT). The larvae were considered satiated when they stopped searching the food. The leftover food was removed from the bowls after $1 \mathrm{~h}$ of food application. Each bowl was cleaned once daily before providing food in the morning. All the experimental bowls were under same management protocol. Broken earthen pots locally known as "chara" was used as a shelter in the bowls as the larvae have a tendency to hide under the shelter. The experiment was continued for 21 days. During the study, water temperature by using a celcius thermometer, $\mathrm{pH}$ by a portable digital $\mathrm{pH}$ meter (MICRO-TEMP, $\mathrm{pH}$ 500), and dissolved oxygen (DO) by a digital DO meter (multi 340 i/set, DO-5509; Germany) were recorded as $26.4 \pm 0.9{ }^{\circ} \mathrm{C}$, $7.5 \pm 0.3$, and $6.7 \pm 0.5 \mathrm{ppm}$, respectively.

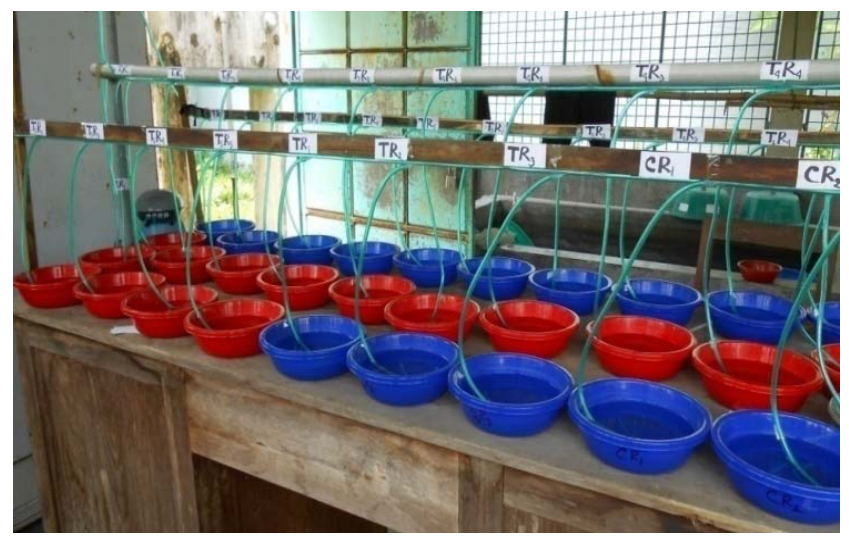

Fig. 3. Hatching devices for fertilized eggs of Heteropneustes fossilis under different sumithion concentrations

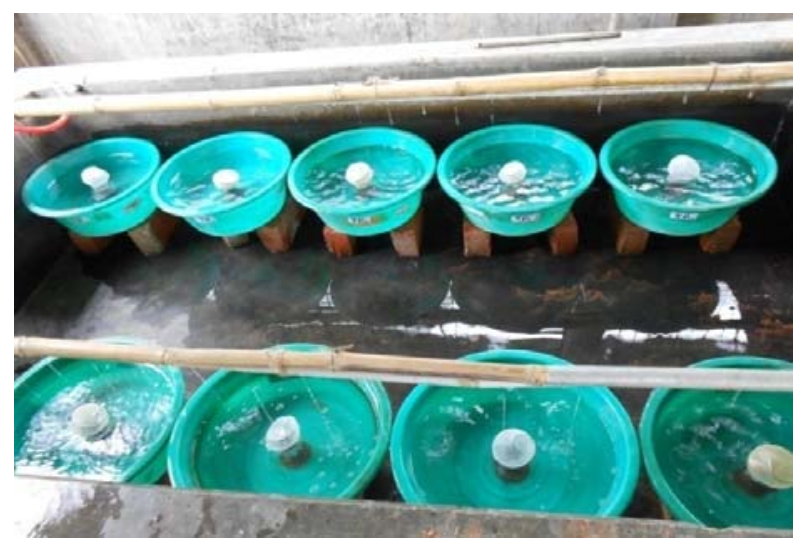

Fig 4. Heteropneustes fossilis larvae rearing unit

\section{Performance evaluation of $\boldsymbol{H}$. fossilis larvae}

Periodic sampling was done every 7 days interval to assess the health condition of larvae. Ten larvae were randomly collected from each of the bowl by a small scoop net for measuring their length and weight. Weight was taken by a sensitive portable digital electric balance (METTLER TOLEDO, Switzerland) and the length by placing the larvae on a petridish placed on a graph paper. Furthermore, 
the final mean length, weight, survival and specific growth rate (SGR) of larvae were recorded at the time of final harvesting. Sampling was done before the application of food to avoid the biasness of weight due to presence of excessive food. The following parameters were considered:

Percent length gain $=\frac{\text { Average final length }- \text { Average initial length }}{\text { Average initial length }} \times 100$
Percent weight gain $=\frac{\text { Average final weight }- \text { Average initial weight }}{\text { Average initial weight }} \times 100$

Specific growth rate:

$$
\operatorname{SGR}(\% \text { day })=\frac{\ln W_{2}-\ln W_{1}}{T_{2}-T_{1}} \times 100(\text { Brown, 1957) }
$$

Where, $W_{2}=$ Final live body weight at time $T_{2}$ $\mathrm{W}_{1}=$ Initial live body weight at time $\mathrm{T}_{1}$

Percent survival $(\%$ survival $)=\frac{\text { Number of larvae alive }}{\text { Total number of larvae stocked }} \times 100$

\section{Statistical analysis}

The evaluations of the treatment mean were made by using one-way analysis of variance (ANOVA). Significant results were tested by using Duncan Multiple Range Test (DMRT) to identify the specific differences among the means. Data obtained from the sumithion acute toxicity tests were evaluated using the Probit Analysis Statistical Method. The $\mathrm{LC}_{50}$ values (with $95 \%$ confidence limits) were calculated and the significance level between the $\mathrm{LC}_{50}$ values and the different exposure times was analyzed using a $X^{2}$ test. The statistical data analysis was carried out with the help of the computer software SPSS (SPSS, Chicago, IL, USA) version 16.0.

\section{Results and Discussion}

The total length and weight were observed for sumithion treated and untreated $H$. fossilis from February to May and the values are presented in Table 1. The initial average lengths and weights of sumithion treated and control fish were $17.34 \pm 2.62 \mathrm{~cm}$ and $32.37 \pm 15.32 \mathrm{~g}$, respectively. The final average lengths of sumithion treated and untreated fish were $25 \pm 2.33$ and $27.21 \pm 4.25 \mathrm{~cm}$, respectively and the final average weights were found to be $42.98 \pm 10.13$ and $46.89 \pm 14.21 \mathrm{~g}$, respectively. Although the treated fish apparently showed lower average length and weight than the control group but, statistical analysis showed no significant $(p>0.05)$ difference in growth performance of sumithion treated and untreated fish.

Table 1. Growth performances of sumithion treated and untreated fish in terms of average length and weight during 4 months experimental period

\begin{tabular}{c|cc|cc}
\hline \multirow{2}{*}{ Months } & \multicolumn{2}{|c|}{ Sumithion Treated } & \multicolumn{2}{c}{ Untreated (Control) } \\
\cline { 2 - 5 } & $\begin{array}{c}\text { Length } \mathbf{( c m )} \\
\text { Mean } \pm \text { SD }\end{array}$ & $\begin{array}{c}\text { Weight (g) } \\
\text { Mean } \pm S D\end{array}$ & $\begin{array}{c}\text { Length (cm) } \\
\text { Mean } \pm S D\end{array}$ & $\begin{array}{c}\text { Weight (g) } \\
\text { Mean } \pm S D ~\end{array}$ \\
\hline Initial & $17.34 \pm 2.62$ & $32.27 \pm 15.33$ & $17.34 \pm 2.62$ & $32.27 \pm 15.33$ \\
\hline February & $18.84 \pm 1.91$ & $32.33 \pm 10.42$ & $20.60 \pm 1.59$ & $33.93 \pm 16.49$ \\
\hline March & $20.25 \pm 1.55$ & $34.09 \pm 12.21$ & $22.66 \pm 3.30$ & $37.19 \pm 16.98$ \\
\hline April & $23.19 \pm 1.38$ & $40.16 \pm 12.23$ & $25.08 \pm 3.25$ & $42.04 \pm 13.30$ \\
\hline May & $25.00 \pm 2.33$ & $42.98 \pm 10.12$ & $27.21 \pm 4.25$ & $46.89 \pm 14.21$ \\
\hline
\end{tabular}

In order to determine the effects of sumithion on the breeding performances of $H$. fossilis, breeding trials were given at both sumithion treated and untreated fish in two separate cisterns. No significant difference was found in ovulation rate between sumithion treated and untreated group that is to say, ovulation rate was found to be $100 \%$ in both cases. The fertilization and hatching rates of sumithion treated fish were 72.67 and $64.33 \%$, respectively whereas, such values for untreated fish were 85.33 and $79.33 \%$, respectively. Statistical analysis showed that fertilization and hatching rates of treated group were 
significantly $(p<0.05)$ lower than the control. Bhuiyan et al. $(2001)$ reported that exposure of sumithion at the dose of $100 \mathrm{ppm}$ to sexually mature Channa punctatus showed fragmented ova with abnormal shape and arrangement while normal arrangement of ova was found in case of controlled fish. Sivarajah et al. (1978) observed fragmentation and karyolysis of ova when Salmo gairdneri and Cyprinus carpio were exposed to pesticide aroclor 1254. Jha and Jha (1994) mentioned the impact of urea (416 ppm) and ammonium sulphate $(448 \mathrm{ppm})$ on the ovary of $H$. fossilis. Urea induced initial stimulation of vitellogenesis followed by subsequent arrest of ovarian growth. Moreover, the cells of germinal epithelium developed hyperplasia leading to the complete fusion of the two follicles. Contrary to urea, ammonium sulphate produced severe adverse effects as evident from large number of early non-vitellogenic oocytes and traces of reovulatory degenerated oocytes. These may be reasons for getting lower fertilization and hatching ratesin pesticide treated group compared to that of control.

The acute toxicity of sumithion on the incubation, survival and hatching rates of embryo are presented in Table 2. It has been noticed that increasing sumithion concentrations has significant effects on incubation period, survival and hatching success of fertilized eggs of $H$. fossilis. The incubation period of $H$. fossilis embryo was estimated at 20.18 to $24.24 \mathrm{~h}$ for different sumithion doses and $19.17 \mathrm{~h}$ for control group. Statistical analysis revealed that incubation period increased significantly $(p<0.05)$ with raising sumithion concentrations in all the treated groups. The present result is strongly supported by the findings of Konar (1969) who found incubation period increases with the increase of pesticide concentration of dichlorvos (2, 2-dichlorovinyl dimethyl phosphate). Marimuthu et al. (2013) found the similar result for incubation of African catfish, Clarias gariepinus when exposed to different buprofezin (an organophosphate insecticide) concentrations that is, the higher the pesticide concentration, the longer the time needed to hatch.

Table 2. Acute toxicity of sumithion on Heteropneustes fossilis embryos and larvae $(n=200$ for initial eggs and larvae in five replicates)

\begin{tabular}{|c|c|c|c|c|c|c|c|}
\hline \multirow[t]{2}{*}{$\begin{array}{c}\text { Concentration } \\
\text { ppm }\end{array}$} & \multicolumn{3}{|c|}{ Embryonic stage } & \multicolumn{4}{|c|}{$\begin{array}{c}\text { Larval stage } \\
\text { Number of dead larvae }\end{array}$} \\
\hline & $\begin{array}{c}\text { Number of } \\
\text { dead } \\
\text { embryos }\end{array}$ & $\begin{array}{l}\text { Hatching } \\
\text { success (\%) }\end{array}$ & $\begin{array}{l}\text { Incubation } \\
\text { period }(\mathrm{h})\end{array}$ & $24 \mathrm{~h}$ & $48 \mathrm{~h}$ & $72 \mathrm{~h}$ & $96 \mathrm{~h}$ \\
\hline 0.5 & $39.2 \pm 4.2$ & $85.0 \pm 2.7$ & 20.2 & $29.2 \pm 6.6$ & $39.6 \pm 4.3$ & $46.0 \pm 4.2$ & $54.2 \pm 5.1$ \\
\hline 1.0 & $49.8 \pm 5.5$ & $76.2 \pm 2.4$ & 21.3 & $38.6 \pm 7.9$ & $48.2 \pm 5.6$ & $55.4 \pm 3.2$ & $65.6 \pm 4.0$ \\
\hline 2.0 & $60.0 \pm 10.1$ & $73.0 \pm 4.9$ & 22.2 & $48.2 \pm 6.3$ & $55.0 \pm 3.8$ & $60.0 \pm 4.3$ & $70.0 \pm 2.4$ \\
\hline 4.0 & $70.8 \pm 8.0$ & $65.0 \pm 4.5$ & 23.2 & $56.4 \pm 6.8$ & $62.4 \pm 5.9$ & $68.8 \pm 4.3$ & $75.6 \pm 4.4$ \\
\hline 8.0 & $85.6 \pm 6.8$ & $51.2 \pm 6.6$ & 24.3 & $80.4 \pm 4.5$ & $84.0 \pm 6.0$ & $89.8 \pm 6.5$ & $97.8 \pm 7.4$ \\
\hline Control & $9.4 \pm 3.4$ & $90.8 \pm 3.2$ & 19.7 & $3.4 \pm 2.9$ & $5.4 \pm 2.5$ & $9.6 \pm 1.8$ & $17.0 \pm 2.8$ \\
\hline$x^{2}$ value & 46.370 & - & - & 68.093 & 68.835 & 57.658 & 50.101 \\
\hline P value & $<0.05$ & & & $<0.05$ & $<0.05$ & $<0.05$ & $<0.05$ \\
\hline $\begin{array}{l}\mathrm{LC}_{50} \text { value }(\mathrm{ppm}) \\
\text { with } 95 \% \\
\text { confidence limits }\end{array}$ & $\begin{array}{c}7.803 \\
(6.997-8.927)\end{array}$ & - & - & $\begin{array}{l}8.677^{\mathrm{a}} \\
(7.612- \\
10.289)\end{array}$ & $\begin{array}{l}8.245^{\text {ab }} \\
(7.205- \\
9.832)\end{array}$ & $\begin{array}{l}7.664^{\mathrm{c}} \\
(6.778- \\
8.961)\end{array}$ & $\begin{array}{l}6.782^{\mathrm{d}} \\
(6.064- \\
7.791)\end{array}$ \\
\hline
\end{tabular}

$\mathrm{LC}_{50}$ values with different superscripts are significantly different $(p<0.05)$.

The $24 \mathrm{~h} \mathrm{LC}_{50}$ value (95\% confidence limits) of sumithion for embryos was found to be 7.803 (6.997$8.927) \mathrm{ppm}$. The survival and hatching rates of fertilized eggs decreased with the increased sumithion concentration from 0.5 to $8 \mathrm{ppm}$. The survival rates of embryo at $0.5,1.0,2.0,4.0$, and $8.0 \mathrm{ppm}$ were $80.40,78.00,74.00,71.00$, and $68.20 \%$, respectively whereas; in control the survival rate was found to be $83.20 \%$. The hatching rates of fertilized eggs when exposed to $0.5,1.0,2.0,4.0$, and $8.0 \mathrm{ppm}$ sumithion were found to be $85.0,76.2,73.0,65.0$, and $51.2 \%$, respectively while $90.8 \%$ for control group (Table 2). Statistical analysis showed that both survival and hatching rates of $H$. fossilis embryo at 1.0, 2.0, 4.0, and $8.0 \mathrm{ppm}$ were significantly $(p<0.05)$ lower than that of control group. Among the five treated groups, the survival and hatching successes of eggs at $0.5 \mathrm{ppm}$ was found significantly higher $(p<0.05)$ than those of others. Takimoto et al. (1984) stated that exposure time of Oryzias latipes embryos to increasing concentrations of the organophosphate fenitrothion (sumithion) resulted in significantly different degrees 
of mortality and hatching success. Marimuthu et al. (2013) described that mortality of embryo of African catfish, C. gariepinus increased significantly with increasing buprofezin concentrations from 5 to $100 \mathrm{ppm}$. They also described that increasing buprofezin concentrations has significant effects on hatching success of fertilized eggs. The number of dead embryos has also been found to increase significantly with the increasing concentration of an organophosphate pesticide diazinon for $0.25,0.5,1$, and 2,4 to $8 \mathrm{ppm}$ (Aydin and Koprucu, 2005). The present findings strongly support the results of the Marimuthu et al. (2013), Takimoto et al. (1984), and Aydin and Koprucu (2005). These observations clearly indicated that, sumithion has great adverse effects on the embryonic development of $H$. fossilis. However, more study is required to find out how sumithion interfere specifically the normal development and hatching process of H. fossilis embryo.

In the larval stage, the number of dead larvae at certain sumithion doses was examined in relation to the duration $(24,48,72$, and $96 \mathrm{~h})$ of exposure. The number of dead larvae significantly increased with increasing concentrations exposed for 24-96 h. There were significant differences in number of dead larvae between the exposure times $24-96 \mathrm{~h}$ and in each concentration $(p<0.05)$. The highest concentration of $8 \mathrm{ppm}$ showed the highest larval mortality. The 24, 48, 72, and $96 \mathrm{~h} \mathrm{LC} 50$ values (with $95 \%$ confidence limits) of sumithion for $H$. fossilis larvae were estimated to be 8.677 (7.612-10.289), 8.245 (7.205-9.832), 7.664 (6.778-8.961), and 6.782 (6.064-7.791) ppm, respectively (Table 2). There were significant differences in the $L_{50}$ values obtained at different exposure times $(p<0.05)$ and we found here sumithion to be highly toxic to $H$. fossilis larvae. During development sensitivity may change with some compounds showing higher sensitivity in embryos whereas others are more toxic to larvae (Fent and Meier, 1994; Gaikowski, 1996). There are differences in the acute toxicity of sumithion for various fish species. In European eel (Anguilla anguilla), the $96 \mathrm{~h} \mathrm{LC}{ }_{50}$ values range even in hundredths ppm (Sancho et al., 1993). The $96 \mathrm{~h} \mathrm{LC}{ }_{50}$ values of an organophosphate diazinon was reported as $0.1-0.5 \mathrm{ppm}$ for fry bluegill (Lepomis macrochirus), $0.88 \mathrm{ppm}$ for American oyster (Crassostrea virginica), $1.47 \mathrm{ppm}$ for sheepshead minnow (Cyprinodon variegates), $1.65 \mathrm{ppm}$ for fry rainbow trout (O. mykiss), and $7.80 \mathrm{ppm}$ for fathead minnow, Pimephales minnow (2000; Available at http://www.epa.govt.nz/; accessed July 2016). Again, the $96 \mathrm{~h} \mathrm{LC}_{50}$ values of diazinon for guppy (Poecilia reticulate) was found to be $0.8 \mathrm{ppm}$ but for zebra fish (Brachydanio rerio) it was found to be 8 ppm (Keizer et al., 1991). Oh et al. (1991) presented three factors causing the selective toxicity of organophosphate for various fish species: different inhibition of acety Icholinesterase, different detoxification and absorption.

Larvae produced from the pesticide exposed groups of three concentrations such as, $0.5,2.0$, and 8.0 ppm of sumithion were further reared in underground water to observe the effects of remaining sumithion on the subsequent growth and survival of the $\mathrm{H}$. fossilis larvae. The result of the growth parameters for instance, percent length gain and percent weight gain, SGR and survival rate of larvae are summarized in Table 3. The percent length gains of the larvae produced from the control, $0.5,2.0$, and $8.0 \mathrm{ppm}$ were $640 \pm 12.65,599 \pm 29.46,415.675 \pm 22.14$, and $373.50 \pm 26.84 \mathrm{~mm}$, respectively and percent weight gains were $2318.94 \pm 58.79,1701.98 \pm 18.28,1324.87 \pm 14.83$, and $1109.21 \pm 75.25 \mathrm{mg}$, respectively. Significant differences $(p<0.05)$ were found among the treated groups at both percent length gains and percent weight gains of the larvae. Amid the treated groups, larvae produced from $0.5 \mathrm{ppm}$ sumithion showed the highest percent length gain and percent weight gain compared to 2.0 and $8.0 \mathrm{ppm}$.

The final SGR and survival rate of the larvae of $H$. fossilis were investigated and both the parameters were found significantly $(p<0.05)$ different within the control and treated groups. The SGR and survival rate decreased significantly with increase of sumithion concentrations. The final SGR values in control, $0.5,2.0$, and $8.0 \mathrm{ppm}$ were determined as $15.17 \pm 0.12,13.77 \pm 0.05,12.65 \pm 0.05$, and $11.85 \pm 0.12 \mathrm{~mm}$, respectively, and the survival rates were found to be $80.5 \pm 2.08,71.25 \pm 2.63,61.75 \pm 3.30$, and $54 \pm 4.76 \mathrm{mg}$, respectively (Table 3 ). These results suggested that the larvae produced from the fertilized eggs treated with $0.5,2.0$, and $8.0 \mathrm{ppm}$ of sumithion had significantly $(p<0.05)$ lower SGR and survival rate compared to those of control group after 21 days of experimental period. The SGR and survival rate of the larvae among the treated groups were also significant and the larvae produced from the eggs treated with 0.5 ppm sumithion showed significantly $(p<0.05)$ higher SGR and lower mortality than those of 2.0 and 8.0 $\mathrm{ppm}$, respectively. The results of this study revealed that the increase of sumithion concentrations to the 
fertilized eggs of $H$. fossilis decreased growth and survival indicating toxic nature of sumithion to the $H$. fossilis larvae. Kabir et al. (2013), found similar mortality trend when $H$. fossilis larvae were treated with different sumithion doses that is, the mortality rates of the larvae gradually increased with the increasing concentrations of sumithion even in lower dose (from $145 \mu \mathrm{g} / \mathrm{L}$ to $314 \mu \mathrm{g} / \mathrm{L}$ ). Our results are similar to those of many previous studies, decreased growth performance and increased mortality of the larvae in accordance with the increased pesticide concentrations (Rashid et al., 2012; Machova, 2010). The results of the current study denote that exposure of sumithion exerts developmental toxicity, creates deformities, and enhances mortality of larvae; and thus the toxic effect of sumithion to $H$. fossilis eggs, embryos and larvae are irreversible.

Table 3. Growth and survival rates of $\boldsymbol{H}$. fossilis larvae produced from three different sumithion concentrations during 21 days experimental period

\begin{tabular}{|c|c|c|c|c|c|}
\hline $\begin{array}{c}\text { Sumithion } \\
\text { concentraions } \\
(\mathrm{ppm})\end{array}$ & Replication & $\begin{array}{l}\text { Percent length } \\
\text { gain }(\mathrm{mm})\end{array}$ & $\begin{array}{l}\text { Percent weight } \\
\text { gain }(\mathrm{mg})\end{array}$ & $\begin{array}{c}\text { SGR } \\
\text { (\% day) }\end{array}$ & $\begin{array}{c}\text { Survival rate } \\
(\%)\end{array}$ \\
\hline \multirow{5}{*}{0.5} & R1 & 620.00 & 1697.37 & 13.76 & 75 \\
\hline & R2 & 580.00 & 1692.12 & 13.74 & 70 \\
\hline & R3 & 628.00 & 1728.95 & 13.84 & 69 \\
\hline & R4 & 568.00 & 1689.47 & 13.74 & 71 \\
\hline & Mean \pm SD & $599.00^{b} \pm 29.46$ & $1701.98^{b} \pm 18.28$ & $13.77^{6} \pm 0.05$ & $71.25^{b} \pm 2.63$ \\
\hline \multirow{4}{*}{2.0} & R1 & 391.50 & 1310.00 & 12.60 & 66 \\
\hline & R2 & 405.20 & 1318.42 & 12.63 & 62 \\
\hline & R3 & 423.60 & 1344.74 & 12.72 & 61 \\
\hline & R4 & 442.40 & 1326.32 & 12.65 & 58 \\
\hline \multicolumn{2}{|c|}{ Mean \pm SD } & $415.68^{c} \pm 22.14$ & $1324.87^{c} \pm 14.83$ & $12.65^{c} \pm 0.05$ & $61.75^{c} \pm 3.30$ \\
\hline \multirow{4}{*}{8.0} & R1 & 344.80 & 1150.00 & 12.02 & 57 \\
\hline & $\mathrm{R} 2$ & 356.80 & 1005.26 & 11.44 & 59 \\
\hline & R3 & 400.00 & 1176.32 & 12.12 & 51 \\
\hline & R4 & 392.40 & 1105.26 & 11.85 & 49 \\
\hline \multicolumn{2}{|c|}{ Mean \pm SD } & $373.50^{d} \pm 26.85$ & $1109.21^{\mathrm{d}} \pm 26.85$ & $11.86^{d} \pm 0.30$ & $54.00^{\mathrm{d}} \pm 4.76$ \\
\hline \multirow{4}{*}{ control } & R1 & 624.00 & 2231.00 & 14.99 & 81 \\
\hline & $\mathrm{R} 2$ & 652.00 & 2352.63 & 15.23 & 80 \\
\hline & R3 & 648.00 & 2350.00 & 15.23 & 83 \\
\hline & R4 & 636.00 & 2342.12 & 15.23 & 78 \\
\hline \multicolumn{2}{|c|}{ Mean : } & $640.00^{\mathrm{a}} \pm 12.65$ & $2318.94^{a} \pm 58.78$ & $15.17^{a} \pm 0.12$ & $80.50^{a} \pm 2.08$ \\
\hline
\end{tabular}

Mean values in the column with different superscripts are significantly different at $P<0.05$.

\section{Conclusion}

Long term exposure to pesticides causes a continuous health hazard of fish population. So, human population is at high risk by consuming these toxicated fishes. Therefore, attention must be given to the adverse effects of sumithion as well as other similar pesticides on non-targeted aquatic species. It could be said that sumithion contamination is dangerous to the aquatic ecosystems, and the issue should be taken into consideration when this pesticide is used in agriculture or in the control of insect populations. The findings of current research highlights that, exposure of sumithion to $H$. fossilis at an earlier stage of the life cycle significantly reduces the number of returning adults. However, for a safe use of this pesticide to the aquatic ecosystem, more research work should be carried out to determine the appropriate concentration and duration that will not induce remarkable sub-lethal effects to fish.

\section{Acknowledgements}

The study was supported by the Grants from Government of the People's Republic of Bangladesh, Dhaka, Bangladesh as well as Bangladesh Fisheries Research Institute (BFRI), Mymensingh.

\section{Conflict of interest}

We, the authors, declare that we have no conflict of interest. 


\section{References}

APHA, 1957. American Public Health Association. Standard Methods for the Examination of Water and Wastewater, ed. $16^{\text {th }}$, District of Columbia: Washington, pp. 1268.

Aydin, R., Koprucu, K. 2005. Acute toxicity of Diazinon on the common carp (Cyprinus carpio L.) embryos and larvae. Pestic. Biochem. Physiol., 82: 220-225.

Bhuiyan, A.S., Nesa, B., Nessa, Q. 2001. Effects of sumithion on the histological changes of spotted murrel, Channa punctatus (Bloch). Pak. J. Biol. Sci., 4: 1288-1290.

Brown, M.E. 1957. Experimental studies on growth. In: Brown, M. E. (ed); The Physiology of Fishes, Academic Press, New York, pp. 361-400.

Fent, K., Meier, W. 1994. Effects of triphenyltin on fish early life stages. Arch. Environ. Contam. Toxicol., 27: 224-231.

Gaikowski, M.P., Hamilton, S.J., Buhl, K.J., McDonald, S.F., Summers, C.H. 1996. Acute toxicity of fire fighting chemical formulations to four life stages of fathead minnow. Ecotoxicol. Environ. Saf., 34: 252-263.

Haque, M.Z., Barua, G. 1988. Toxic and sub-lethal effect of sumithion on Oreochromis nilotica (Lin.). Bangladesh J. Fish., 11: 79-85.

Jha, B.K., Jha, B.S. 1994. Ovarian histopathology in urea and ammonium sulphate intoxicated freshwater teleost, Heteropneustes fossilis. Int. J. Environ. Pollut., 1: 145-148.

Kabir, M.F., Bhowmik, L.R., Motin, M.A., Haq, M.S., Alahe, K.E., Shahrin, T., Rashid, H. 2013. Effect of the insecticide sumithion on larval development in Heteropneustes fossilis. Proceedings of $4^{\text {th }}$ the International Conference on Environmental Aspects of Bangladesh, Fukuoka, Japan, 132-136.

Keizer, J., DeAgostino, G., Vittozzi, I. 1991. The importance of biotransformation in the toxicity of xenobiotics to fish. 1: toxicity and bioaccumulation of diazinon in guppy (Poecilia reticulata) and zebra fish (Brachydanio rerio). Aquat. Toxicol., 21: 239-254.

Konar, S.K. 1969. Laboratory studies on two organophosphorus insecticides toxicity. Trans. Am. Fish. Soc., 98: 430-437.

Koundinya, P.R., Ramamurthy, R. 1978. Effect of sumithion (Fenithrothion) on some selected enzyme systems in the fish, Tilapia mossambica (Peters). Indian J. Exp. Biol., 18: 809-811.

Machova, J., Prokes, M., Penaz, M., Barus, V., Leuropova, H. 2010. Toxicity of Diazinon 60 EC for embryos and larvae of tench, Tinca tinca (L). Rev. Fish. Biol. Fish., 20: 409-415.

Marimuthu, K., Muthu, N., Xavier, R., Arockiaraj, J., Rahman, M.A., Subramanian, S. 2013. Toxicity of Buprofezin on the survival of embryo and larvae of African catfish, Clarias gariepinus (Bloch). Plos One, 8: 3-14.

Minister, R.T., Berg, G.L., Sine, C., Meister, S., Poplylc, J. 1984. Farm chemical handbook.70 ${ }^{\text {th }}$ ed, Meister Publishing Co. Willoughby, $\mathrm{OH}$.

Office of Pesticide Programs, Pesticide Ecotoxicity Database (Formerly: Environmental Effects Database), Environmental Fate and Effects Division, U.S. EPA, Washington, DC, 2000, Available at http://www.epa.govt.nz/ (accessed July 2016).

Oh, H.S., Lee, S.K., Kim, Y.H., Roh, J.K. 1991. Mechanism of selective toxicity of diazinon to killifish (Oryzias latipes) and loach (Misgurnus anguillicaudatus). Aquat. Toxicol. Risk. Assess., 14: 343-353.

Pawar, K.R., Katdare, M. 1982. Effect of the insecticide sumithion (fenitrothion) on embryonic development in a frog. Cell. Mol. Life Sci., 39: 297-298.

Rashid, H., Bhowmik, L.R., Taslima, K., Alam, M.J., Rakeya, U.K., Paul, S.P. 2012. Toxicity of Diazinon on embryonic and larval development of stinging catfish, Heteropneustes fossilis. Proceedings of the $3^{\text {rd }}$ International Conference on Environmental Aspects of Bangladesh, Fukuoka, Japan, pp. 47-50.

Sabra, F.S., Mehana, S.D. 2015. Pesticides Toxicity in fish with particular reference to Insecticides. Asian J. Agric. Food Sci., 3: 4060.

Sancho, E., Ferrando, M.D., Andreu, E. 1998. Physiological stress responses of Anguilla anguilla to fenitrothion. Effects of sublethal exposure to a pesticide on levels of energetic compounds in Anguilla anguilla. J. Environ. Sci. Health. B., 33: 411-424.

Sancho, E., Ferrando, M.D., Andreau, E., Gamon, M. 1993. Bioconcentration and excretion of diazinon by eel. Bull. Environ. Contam. Toxicol., 50: 578-585.

Saxena, A.B., Sehgal, R. 1986. Pesticide toxicity to a freshwater fish Channa puctatus in the river Shipra Ujjain, India. IRTL. Environment and safety Conference Publication, International and Safety Limited of UK, 65-66.

Sivarajah, K., Franklinand, C.S., Williams, W.P. 1978. Some histopathological effects of Aroclor 1254 on the liver and ovaries of rainbow trout, Salmo gairdneri and carp, Cyprinus carpio. J. Fish. Biol., 13: 411-414.

Takimoto, Y., Hagino, S., Yamada, H., Miyamoto, J. 1984. The acute toxicity of Fenitrothion to killifish (Oryzias latipes) at twelve different stage of its life history. J. Pestic. Sci., 9: 463-470.

Talwar, P.K., Jhingran, A.G. 1992. Inland fishes of India and adjacent countries, Vol. 2. Oxford and IBH publishing company private limited, New Delhi, India.

Tripathi, S.H., Ross, N., Hasan, N. 1997. The role of small indigenous species in food and nutritional security in Bangladesh. NAGA News Letter, July-December. 